\author{
Made Sukma Prasitadewi1 \\ Fakultas Ekonomi dan Bisnis \\ Universitas Udayana, Indonesia \\ Email: sukmadewi689@gmail.com
}

\author{
I Nyoman Wijana Asmara Putra ${ }^{2}$ \\ Fakultas Ekonomi dan Bisnis \\ Universitas Udayana, Indonesia
}

\begin{abstract}
ABSTRAK
Tujuan penelitian ini adalah untuk mengetahui pengaruh profitabilitas, kebijakan dividen, keputusan pendanaan, inflasi, suku bunga dan nilai tukar mata uang. Penelitian ini mengambil sampel pada perusahaan manufaktur yang terdaftar di Bursa Efek Indonesia periode tahun 2016-2018. Teknik yang digunakan dalam penelitian ini adalah analisis regresi linier berganda. berdasarkan hasil analisis penelitian ini membuktikan bahwa Profitabilitas berpengaruh positif terhadap nilai perusahaan. Kebijakan dividen tidak berpengaruh terhadap nilaiperusahaan. Keputusan pendanaan berpengaruh negatif terhadap nilai perusahaan. Tingkat inflasi berpengaruh negatif pada nilai perusahaan. Tingkatsuku bunga berpengaruhnegatif pada nilai perusahaan. Nilai tukar mata uang berpengaruh negatif pada nilai perusahaan.
\end{abstract}

Kata Kunci: Profitabilitas; Kebijakan Dividen; Keputusan Pendanaan; Inflasi, Suku Bunga; Nilai Tukar Mata Uang.

\section{The Influence of Internal Factors and External Factors on Company Value}

\begin{abstract}
The purpose of this study was to determine the effect of profitability, dividend policy, funding decisions, inflation, interest rates and currency exchange rates. This study took a sample of manufacturing companies listed on the Indonesia Stock Exchange in the period 2016 2018. The technique used in this research is multiple linear regression analysis. based on the results of the analysis of this study proves that profitability has a positive effect on firm value. Dividend policy does not affect the value of the company. Funding decisions negatively affect the value of the company. Inflation has a negative effect on firm value. Interest rates have a negative effect on firm value. Currency exchange rates have a negative effect on company value.
\end{abstract}

Keywords: Profitability; Dividend Policy; Funding Decision; Inflation; Interest Rates; Currency Exchange Rates.

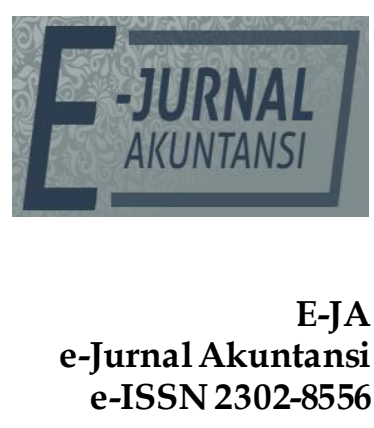

Vol. 30 No. 6

Denpasar, Juni 2020

Hal.1397-1413

Artikel Masuk: 20 Januari 2020

Tanggal Diterima: 27 Februari 2020

This Article is Avalilable in: https://ojs.unud.ac.id/index.php/Akuntansi/index 


\section{PENDAHULUAN}

Nilai perusahaan dapat dilihat dari kemampuan perusahaan membayar dividen. Jika perusahaan memutuskan dividen dibayar tinggi, maka harga saham cenderung tinggi sehingga nilai perusahaan juga tinggi. Sebaliknya jika dividen yang dibayarkan kecil maka harga saham perusahaan tersebut juga rendah. Kemampuan membayar dividen erat hubungannya dengan kemampuan perusahaan memperoleh laba. Jika perusahaan memperoleh laba yang besar, maka kemampuan membayar dividen juga besar. Oleh karena itu, dividen yang besar akan meningkatkan nilai perusahaan (Rakhimsyah, 2011).

Pendistribusian laba berupa dividen atau penahanan dana untuk mendanaan proyek dimasa depan disebut kebijakan dividen. Kebijakan dividen tetap menjadi salah satu kebijakan keuangan yang terpenting untuk sebuah perusahaan. Kebijakan dividen membawa informasi tentang prospek perusahaan untuk pertumbuhan laba di masa depan dan informasi tersebut dapat mengundang respon dari investor sehingga akan memengaruhi nilai perusahaan (Chandra, Fachrudin, Sadalia, \& Siburian, 2017). Para investor memiliki tujuan utama untuk meningkatkan kesejahteraan dengan mengharapkan pengembalian dalam bentuk dividen maupun capital gain. Seorang investor yang tidak bersedia berspekulasi akan lebih memilih dividen dari pada capital gain.

Keputusan pendanaan yang dilakukan oleh perusahaan juga dapat mempengaruhi nilai perusahaan. Atmaja (2003) mengatakan bahwa seorang manajer harus mampu untuk mengambil keputusan pendanaan dengan mempertimbangkan komposisi hutang dan modal sendiri yang akan digunakan oleh perusahaan. Debt to equity ratio (DER) adalah satu rasio yang digunakan untuk mengukur efektivitas suatu pendanaan dengan mempertimbangkan hutang dan modal sendiri. Dengan adanya komposisi yang optimal dari penggunaan hutang dan modal sendiri akan dapat mempengaruhi nilai perusahaan.

Menurut (Alfredo et al., 2011) bahwa semakin kecil rasio Debt to equity ratio (DER), semakin baik kemampuan perusahaan untuk bertahan dalam kondisi yang buruk. Hutang yang terlalu besar juga akan berkaitan pula nantinya dengan risiko keuangan yang akan ditanggung oleh perusahaan dan memperbesar kemungkinan terjadinya risiko kebangkrutan. Penambahan hutang yang digunakan untuk mendanai aktiva akan mengakibatkan semakin besarnya kemungkinan kesulitan perusahaan dalam membayar kewajiban tetap berupa bunga dan pokoknya. Hal ini tentunya akan menurunkan nilai perusahaan dan mengakibatkan risiko kebangkrutan yang lebih tinggi (Mulianti, 2010).

Tandelilin (2010) menyatakan prospek perusahaan tergantung dari keadaan ekonomi secara keseluruhan, oleh kerena itu perusahaan harus mempertimbangkan lingkugan ekonomi makro karena investor akan memperhitungkan beberapa variabel ekonomi makro yang mempengaruhi kemampuan perusahaan untuk menghasilkan laba yang nantinya berpengaruh pada nilai perusahaan. Lingkungan ekonomi makro merupakan lingkungan yang mempengaruhi operasi perusahaan sehari-hari. Kemampuan investor dalam memahami dan meramalkan kondisi ekonomi makro di masa datang akan sangat mempengaruhi keputusan investasi investor sehingga mempengaruhi nilai perusahaan. Seorang investor biasanya mempertimbangkan beberapa 
indikator ekonomi makro yang bisa membantu investor dalam membuat keputusan investasinya. Indikator ekonomi makro yang seringkali dihubungkan dengan pasar modal adalah inflasi dan fluktuasi tingkat bunga.

Variabel makro yang perlu diperhatikan yang dapat mempengaruhi nilai perusahaan adalah inflasi, tingkat inflasi yang tinggi biasanya dikaitkan dengan kondisi ekonomi yang terlalu panas (overheated). Artinya, kondisi ekonomi mengalami permintaan atas produk yang melebihi kapasitas penawaran produknya, sehingga harga-harga cenderung mengalami kenaikan. Jika tingkat inflasi suatu negara mengalami penurunan, maka hal ini akan merupakan sinyal yang positif bagi investor seiring dengan turunnya risiko daya beli uang dan risiko penurunan pendapatan riil (Tandelilin, 2010). Inflasi yang terlalu tinggi akan menyebabkan penurunan daya beli uang dan mengurangi tingkat pendapatan riil yang diperoleh investor dari investasinya yang mengakibatkan para investor enggan menanamkan dananya di perusahaan sehingga nilai perusahaan menurun.

Demikian pula halnya dengan tingkat suku bunga. Suku bunga adalah kebijakan ekonomi disuatu negara jika inflasi meningkat mengakibatkan suku bunga juga akan meningkat. Suku bunga adalah harga dari penggunaan uang untuk jangka waktu tertentu atau harga dari penggunaan uang yang dipergunakan pada saat ini dan akan dikembalikan pada saat mendatang (Herman, 2003). Menurut Tandelilin (2010) tingkat suku bunga yang tinggi akan mempengaruhi nilai sekarang aliran kas perusahaan, sehingga kesempatan investasi yang ada tidak akan menarik lagi. Hal ini akan membuat investor mengurangi investasi sehingga harga saham turun dan nilai perusahaan juga akan mengalami penurunan. Sujoko \& Ugy (2007) juga menyatakan suku bunga yang tinggi akan mengurangi minat investor untuk menginvestasikan dananya ke pasar modal dan lebih memilih berinvestasi pada deposito sehingga aktivitas perdagangan saham akan menurun dan nilai perusahaan juga akan mengalami penurunan. Suku bunga yang berlaku di Indonesia adalah suku bunga Bank Indonesia (SBI).

Faktor eksternal ketiga yang dianggap mempengaruhi nilai perusahaan adalah nilai tukar atau kurs mata uang (exchange rate). Apabila terjadi apresiasi ataupun depresiasi nilai tukar mata uang nasional dinilai akan bisa mempengaruhi nilai suatu perusahaan (Martini et al., 2014). Sebagai misal terjadi depresiasi nilai tukar nasional, sementara perusahaan yang bersangkutan bergantung pada bahan baku import, maka akan terjadi kenaikan biaya produksi dan selanjutnya berdampak mengurangi keuntungan yang diperoleh. Berkurangnya nilai keuntungan yang dicapai akan memunculkan statement negative dan membuat para investor enggan untuk berinvestasi pada perusahaan itu, dan pada akhirnya akan menurunnya nilai perusahaan ni pasar (Gray Jr, 2016).

Penelitian mengenai hubungan profitabilitas dengan nilai perusahaan belum menunjukkan hasil yang konsisten diantara peneliti. Penelitian yang dilakukan oleh Pratama \& Wirawati (2016) menemukan hasil bahwa profitabilitas berpengaruh positif terhadap nilai perusahaan. Arah positif tersebut memiliki arti bahwa semakin meningkat profitabilitas maka nilai perusahaan yang diperoleh juga meningkat. Hasil penelitian tersebut selaras 
dengan hasil penelitian yang dilakukan Kurniawan \& Putra (2019), Manurung et al. (2014), serta Indasari \& Yadnyana (2018), berbeda dengan penelitian yang dilakukan oleh Ustiani (2015) menemukan hasil bahwa profitabilitas tidak memiliki pengaruh terhadap nilai perusahaan. Hasil penelitian tersebut selaras dengan hasil penelitian yang dilakukan Pratiwi \& Mertha (2017).

Penelitian mengenai hubungan kebijakan dividen dengan nilai suatu perusahaan belum menunjukkan hasil yang konsisten diantara peneliti. Penelitian yang dilakukan oleh Octaviani \& Astika (2016) menemukan bahwa kebijakan dividen berpengaruh positif terhadap nilai perusahaan, selaras dengan penelitian Suartawan \& Yasa (2017), dan Wirasedana (2018). Di sisi lain, Riska et al. (2017) menemukan bahwa kebijakan dividen berpengaruh negarif terhadap nilai perusahaan.

Penelitian mengenai hubungan keputusan pendanaan dengan nilai perusahaan belum menunjukkan hasil yang tidak konsisten diantara peneliti. Penelitian yang dilakukan oleh Rizqia et al. (2013) dan Prihantini (2009) menyatakan bahwa keputusan pendanaan berpengaruh negatif dan signifikan terhadap nilai perusahaan. Sedangkan penelitian menurut Hidayati (2010) menyatakan bahwa keputusan pendanaan berpengaruh negatif tetapi tidak signifikan terhadap nilai perusahaan.

Penelitian mengenai hubungan inflasi dengan nilai suatu perusahaan belum menunjukkan hasil yang konsisten diantara peneliti. Penelitian yang dilakukan oleh Permana \& Rahyuda (2018), Windasari (2015), dan Sucuahi (2016) menyatakan bahwa tingkat inflasi berpengaruh negatif dan signifikan terhadap nilai perusahaan. Sedangkan penelitian menurut Hamidah (2015) dan Ningsih (2012) menyatakan bahwa tingkat inflasi berpengaruh negatif tetapi tidak signifikan terhadap nilai perusahaan.

Penelitian mengenai hubungan tingkat suku bunga dengan nilai suatu perusahaan belum menunjukkan hasil yang konsisten diantara peneliti. Penelitian yang dilakukan oleh Setiani (2014) dan Noerirawan (2012) menyatakan bahwa tingkat suku bunga berpengaruh negatif signifikan terhadap nilai perusahaan. Sedangkan penelitian menurut Yunitasari (2014) menyatakan bahwa tingkat suku bunga berpengaruh negatif tetapi tidak signifikan terhadap nilai perusahaan.

Penelitian mengenai hubungan nilai tukar mata uang dengan nilai suatu perusahaan belum menunjukkan hasil yang konsisten diantara peneliti. Penelitian yang dilakukan oleh Mursalim \& Sanusi (2015) menyatakan bahwa nilai tukar mata uang berpengaruh negatif terhadap nilai perusahaan. Sedangkan penelitian menurut (Wangbangpo \& Sharma, 2002), Kandir (2008), M'rabet \& Boujjat (2016), dan Gray Jr (2016) menemukan bahwa nilai tukar memiliki hubungan yang positif terhadap nilai perusahaan.

Penelitian ini menggunakan periode waktu dari tahun 2016-2018. Karena periode waktu dari tahun 2016-2018 belum diteliti pada penelitian-penelitian sebelumnya. Oleh karena itu, penelitian ini dilakukan untuk mengetahui apakah hasil yang akan diperoleh nantinya dapat mendekati hasil atau berbeda hasil dengan penelitian-penelitian sebelumnya. Perbedaan penelitian ini dari penelitian sebelumnya yaitu menggunakan ratio profitabilitas yang di proksi Tobin's $Q$ dan penambahan variabel eksternal dan internal. Alasan peneliti 
memilih perusahaan manufaktur sebagai objek penelitian dikarenakan perusahaan manufaktur merupakan perusahaan yang menjual produknya yang dimulai dengan proses produksi hingga menjadi barang jadi. Perusahaan manufaktur lebih membutuhkan sumber dana jangka panjang untuk membiayai operasi perusahaan mereka, salah satunya dengan investasi saham oleh investor, sehingga dapat mempengaruhi nilai perusahaan (French, 1998).

Penelitian mengenai hubungan profitabilitas dengan nilai perusahaan oleh Sintyana \& Artini (2018) menemukan hasil bahwa profitabilitas berpengaruh positif terhadap nilai perusahan. Arah positif tersebut memiliki arti bahwa semakin meningkat profitabilitas maka nilai perusahaan yang diperoleh juga meningkat. Hasil penelitian tersebut selaras dengan hasil penelitian yang dilakukan Wirasedana (2018), Indasari \& Yadnyana (2018), dan Mursalim Alamzah \& Sanusi (2015). Berdasarkan kajian teoritis, kajian empiris dan dasar logika, maka hipotesis alternative yang diajukan dalam penelitian ini adalah sebagai berikut.

$\mathrm{H}_{1}$ : Profitabilitas berpengaruh positif signifikan pada nilai perusahaan.

Bhattacharya (1979) mengemukakan bahwa pembayaran dividen dapat berfungsi sebagai sinyal kesehatan keuangan perusahaan, dengan peningkatan dividen yang mengindikasikan bahwa manajer mengharapkan bisnis mereka memiliki arus kas yang lebih tinggi di masa depan. Sebagai akibatnya, nilai yang lebih tinggi ditandai oleh dividen yang lebih tinggi. Fama \& French (1998) menemukan bahwa investasi yang dihasilkan dari kebijakan dividen memiliki informasi yang positif tentang perusahaan di masa yang akan datang. Selanjutnya berdampak positif terhadap nilai perusahaan. Penelitian yang dilakukan oleh Octaviani \& Astika (2016) menemukan bahwa kebijakan dividen berpengaruh positif terhadap nilai perusahaan, selaras dengan penelitian Raharjo et al. (2017), dan Pratama \& Wirawati (2016). Bardasarkan kajian teoritis, kajian empiris dan dasar logika, maka hipotesis alternative yang diajukan dalam penelitian ini adalah sebagai berikut.

$\mathrm{H}_{2}$ : Kebijakan dividen berpengaruh positif terhadap nilai perusahaan.

Keputusan pendanaan dapat pula diartikan sebagai keputusan yang menyangkut struktur keuangan perusahaan (financial structure). Struktur keuangan perusahaan merupakan komposisi dari keputusan pendanaan yang meliputi hutang jangka pendek, hutang jangka panjang dan modal sendiri. Keputusan pendanaan diproksikan dengan debt to equity ratio (DER). Menurut Harahap (2010: 303) debt to equity ratio (DER) mengukur kemampuan modal sendiri perusahaan untuk dijadikan jaminan semua utang. Para investor secara umum akan lebih tertarik jika debt to equity ratio lebih rendah. Semakin rendah rasio tersebut maka semakin tinggi tingkat pendanaan perusahaan yang berasal dari pemegang saham, dan perlindungan bagi perusahaan semakin besar jika nilai aktiva menyusut atau ketika terjadi kerugian pada perusahaan. Menurut $\mathrm{Dj}$ et al. (2012) bahwa semakin kecil rasio debt to equity, semakin baik kemampuan perusahaan untuk bertahan dalam kondisi yang buruk.

Perusahaan dengan debt to equity ratio rendah akan memberikan sinyal positif bagi investor dalam mengambil keputusan investasi karena mempunyai resiko kerugian lebih kecil ketika keadaan ekonomi merosot, namun ketika kondisi ekonomi membaik, kesempatan memperoleh laba rendah. Sebaliknya 
perusahaan dengan rasio leverage tinggi, beresiko menanggung kerugian yang besar ketika keadaan ekonomi merosot, tetapi mempunyai kesempatan memperoleh laba besar saat ekonomi membaik. Debt to equity ratio yang terlalu tinggi mempunyai dampak buruk terhadap kinerja perusahaan sehingga berpengaruh terhadap nilai perusahaan, karena tingkat utang yang semakin tinggi berarti beban bunga perusahaan akan semakin besar dan akan mengurangi keuntungan. Penelitian yang dilakukan oleh Yuniasari (2016) mendukung pernyataan bahwa debt to equity rasio berpengaruh negatif dan signifikan terhadap nilai perusahaan. Didukung juga oleh Prihantini (2009) yang menyatakan bahwa debt to equity rasio berpengaruh negatif dan signifikan terhadap nilai perusahaan.

$\mathrm{H}_{3}$ : Keputusan pendanaan berpengaruh negatif signifikan pada nilai perusahaan.

Menurut Judisseno (2002: 16) Inflasi merupakan salah satu peristiwa moneter yang menunjukan suatu kecenderungan akan naiknya harga barangbarang secara umum, yang berarti terjadinya penurunan nilai uang. Menurut Tandelilin (2010) Jika tingkat inflasi suatu negara mengalami penurunan, maka hal ini akan merupakan sinyal yang positif bagi investor seiring dengan turunnya risiko daya beli uang dan risiko penurunan pendapatan riil. Inflasi yang terlalu tinggi akan menyebabkan penurunan daya beli uang dan mengurangi tingkat pendapatan riil yang diperoleh perusahaan sehingga nilai perusahaan menurun yang mengakibatkan para investor enggan menanamkan dananya di perusahaan. Kenaikan harga diukur dengan menggunakan indeks harga konsumen. Penelitian yang dilakukan oleh Prihantini (2009), Permana \& Rahyuda (2018), serta Hamidah \& Hartini (2015) juga mendukung pernyataan bahwa tingkat inflasi berpengaruh negatif terhadap nilai perusahaan.

$\mathrm{H}_{4}$ : Tingkat inflasi berpengaruh negatif signifikan pada nilai perusahaan.

Suku bunga adalah harga dari penggunaan uang untuk jangka waktu tertentu atau harga dari penggunaan uang yang dipergunakan pada saat ini dan akan dikembalikan pada saat mendatang (Herman, 2003). Suku bunga yang tinggi akan memberi sinyal negatif terhadap minat investor untuk menginvestasikan dananya ke pasar modal dan lebih memilih berinvestasi pada deposito sehingga aktivitas perdagangan saham akan menurun dan nilai perusahaan juga akan mengalami penurunan.

Menurut Tandelilin (2010) menyatakan tingkat suku bunga yang tinggi akan mempengaruhi nilai sekarang aliran kas perusahaan, sehingga kesempatan investasi yang ada tidak akan menarik lagi. Hal ini akan membuat investor mengurangi investasi sehingga nilai perusahaan dan harga saham turun juga akan mengalami penurunan. Penelitian yang dilakukan oleh Penelitian (Setiani, 2014) mendukung pernyataan bahwa tingkat suku bunga berpengaruh negatif terhadap nilai perusahaan. Didukung juga oleh penelitian Noerirawan (2012) dan Rukhimsyah (2011) yang menyatakan bahwa tingkat suku bunga SBI berpengaruh negatif terhadap nilai perusahaan.

$\mathrm{H}_{5}$ : Tingkat suku bunga berpengaruh negatif pada nilai perusahaan.

Nilai tukar mata uang (exchange rate) adalah harga suatu mata uang terhadap mata uang yang lain, atau merupakan harga satu unit mata uang asing dalam mata uang domestik ataupun harga satu unit mata uang domestik dalam mata uang asing (Hady, 2016). Derajat stabilitas atas nilai tukar mata uang suatu 
negara dinilai menunjukkan situasi perekonomian negara yang bersangkutan, dan bisa mempengaruhi keyakinan para investor terutama yang berasal dari luar negeri untuk menanamkan modalnya di negara tersebut. Menguatnya nilai tukar rupiah (IDR) terhadap mata uang asing akan memberikan signal positif bagi perkembangan perekonomian Indonesia atau sebaliknya, melemahnya nilai IDR bisa memberi sinyal memburuknya perekonomian nasional (Tandelilin, 2010). Lebih jauh, terjadinya kondisi apresiasi ataupun depresiasi nilai tukar mata uang nasional dinilai akan bisa mempengaruhi nilai suatu perusahaan, dimana investor menghubungkan perkiraan nilai imbalan (rate of return) atau tingkat pertambahan nilai investasi miliknya yang tertanam di pasar modal dengan perkiraan perubahan nilai kurs (Kewal, 2014).

Dalam penelitian ini, nilai tukar diukur menggunakan nilai kurs tengah antara mata uang nasional (IDR) terhadap mata uang dollar (USD) berdasarkan laporan akhir tahun yang dipublikasikan secara rutin oleh Bank Indonesia. Nilai kurs tengah ini digunakan sebagai acuan nilai konversi mata uang asing di dalam laporan keuangan oleh perusahaan-perusahaan yang beroperasi di wilayah Indonesia. Hasil penelitian terdahulu milik Mursalim Alamzah \& Sanusi (2015) menemukan bahwa nilai tukar memiliki hubungan yang negatif dengan nilai perusahaan. Didukung juga oleh penelitian Kusuma (2016), dan Al-abdallah et al. (2017) yang menyatakan bahwa nilai tukar mata uang berpengaruh negatif terhadap nilai perusahaan. Berdasarkan pemikiran bahwa apabila terjadi kenaikan nilai tukar akan menurunkan nilai perusahaan dari perusahaan manufaktur maka dihasilkan hipotesis keenam yaitu:

$\mathrm{H}_{6}$ : Nilai tukar (kurs) berpengaruh negatif pada nilai perusahaan.

\section{METODE PENELITIAN}

Penelitian ini dilakukan pada perusahaan manufaktur yang mencatatkan sahamnya di Bursa Efek Indonesia (BEI) tahun 2016-2017, diakses melalui website $w w w . i d x$.co.id.

Dalam penelitian ini yang menjadi populasi adalah perusahaanperusahaan manufaktur terdaftar di Bursa Efek Indonesia tahun 2016-2018 yang berjumlah sebanyak 150 perusahaan. Teknik penarikan sampel ini adalah purposive sampling atau teknik penarikan sampel dengan pertimbangan tertentu. Populasi yang akan di sampel pada perusahaan manufaktur yang terdaftar di Bursa Efek Indonesia tahun 2016-2018. Hanya elemen populasi yang memenuhi kriteria tertentu dari penelitian saja yang bisa dijadikan sampel penelitian.

Teknik analisis data yang digunakan dalam menganalisis data dalam penelitian ini adalah regresi linear berganda yang diproses dalam menggunakan komputer dengan program stastitical package for social science (SPSS). Persamaan regresi linear berganda ditunjukkan sebagai berikut:

$$
Y=\alpha+\beta_{1} X_{1}+\beta_{2} X_{2}+\beta_{3} X_{3}+\beta_{4} X_{4}+\beta_{5} X_{5}+\beta_{6} X_{6}+e
$$

\section{Keterangan:}

$$
\begin{array}{ll}
\mathrm{Y} & =\text { Nilai Perusahaan } \\
\mathrm{a} & =\text { Nilai Konstanta } \\
\beta_{1}-\beta_{6} & =\text { Koefisien regresi variabel } \mathrm{X}_{1}, \mathrm{X}_{2}, \mathrm{X}_{3}, \mathrm{X}_{4}, \mathrm{X}_{5}, \mathrm{X}_{6} \\
\mathrm{X}_{1} & =\text { Profitabilitas (ROE) } \\
\mathrm{X}_{2} & =\text { Kebijakan Dividen (DPR) }
\end{array}
$$




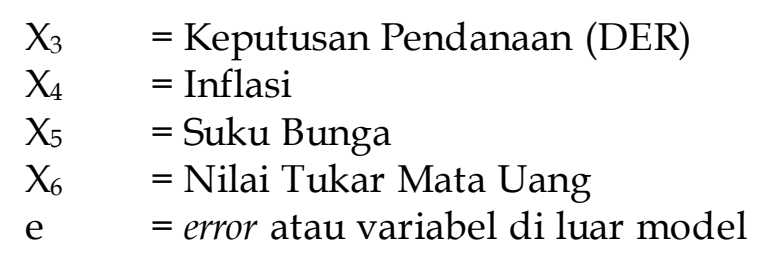

\section{HASIL DAN PEMBAHASAN}

Statistik deskriptif dalam penelitian ini disajikan untuk memberikan informasi mengenai karakteristik variabel-variabel penelitian, antara lain minimum, maksimum, mean, dan standar deviasi. Setelah data dikumpulkan dan diolah ditemukan data mengalami outlier sebanyak 13 buah, sehingga jumlah data pengamatan yang semula 150 menjadi 137 buah. Hasil statistik deskriptif dapat dilihat pada Tabel 1 yaitu sebagai berikut:

Tabel 1. Hasil Statistik Deskriptif

\begin{tabular}{lccccc}
\hline & $N$ & Minimum & Maximum & Mean & Std. Deviation \\
\hline Tobin's Q & 39 & 0,46 & 13,49 & 2,7082 & 3,26434 \\
ROE & 39 & 4,07 & 124,15 & 21,1144 & 27,88759 \\
DPR & 39 & 10,37 & 100,00 & 50,6867 & 28,24744 \\
DER & 39 & 0,08 & 2,12 & 0,6944 & 0,50731 \\
Inflasi & 39 & 3,02 & 3,61 & 3,2533 & 0,25952 \\
Suku Bunga & 39 & 4,56 & 6,00 & 5,2067 & 0,60476 \\
Kurs & 39 & 13,44 & 14,93 & 13,9733 & 0,68682 \\
Valid N (listwise) & 39 & & & & \\
\hline
\end{tabular}

Sumber: Data Penelitian, 2019

Berdasarkan Tabel 1. hasil statistik deskriptif, terdapat berbagai informasi deskripsi dari variabel yang digunakan. Output tampilan Statistical Product and Service Solution (SPSS) menunjukkan jumlah sampel yang digunakan sebanyak 39 (n). Nilai perusahaan yang dinilai menggunakan rasio Tobin's $Q$. Tobin's $Q$ adalah penambahan nilai pasar saham dan nilai pasar hutang dibagi modal yang di tempatkan di aktiva produksi. Tobin's $Q$ memiliki nilai terendah (minimum) sebesar 0,46 pada Unggul Indah Cahaya Tbk tahun 2016 memiliki arti bahwa nilai pasar sahamnya negatif atau terendah sebesar 0,46 persen. Nilai tertinggi (maksimum) sebesar 13,49 pada Unilever Indonesia Tbk tahun 2017 memiliki arti nilai pasar sahamnya tertinggi sebesar 13,49 persen. Nilai rata-rata (mean) data variabel Tobin's $Q$ sebesar 2,7082 memiliki arti 100 rupiah nilai buku total aktiva menghasilkan 2,7082 nilai pasar saham dan nilai buku total hutang, dengan standar deviasi sebesar 3,26434 menunjukkan adanya ketimpangan yang besar nilai Tobin's $Q$ dari 13 perusahaan selama tiga tahun pengamatan.

Variabel profitabilitas yang dinilai menggunakan rasio ROE (Return on Equity) adalah persentase laba bersih setelah pajak dibagi ekuitas perusahaan. Profitabilitas memiliki nilai terendah (minimum) sebesar 4,07 yang terdapat pada Astra Otoparts Tbk pada tahun 2018, memiliki arti bahwa laba perusahaan terendah sebesar 4,07 persen. Nilai tertinggi (maksimum) sebesar 124,15 persen yang terdapat pada Multi Bintang Indonesia Tbk pada tahun 2017, memiliki arti bahwa laba perusahaan tertinggi sebesar 124,15 persen. Nilai rata- rata (mean) sebesar 21,1144 memiliki arti 100 rupiah ekuitas menghasilkan 21,1144 laba bersih setelah pajak, dengan standar deviasi sebesar 27,24744 menunjukkan 
adanya ketimpangan nilai DER dari 13 perusahaan selama tiga tahun pengamatan.

Variabel kebijakan dividen yang dinilai menggunakan rasio DPR (Dividen Payout Ratio) adalah dividen yang dibayar per lembar saham dari saham perusahaan dibanding dengan jumlah laba perusahaan yang dialokasikan kesetiap saham yang beredar. Kebijakan dividen memiliki nilai terendah (minimum) sebesar 10,37 yang terdapat pada Astra Otoparts Tbk pada tahun 2016, memiliki arti bahwa dividen yang dibagikan terendah sebesar 10,37 persen. Nilai tertinggi (maksimum) sebesar 100,00 persen yang terdapat pada Multi Bintang Indonesia Tbk pada tahun 2016, memiliki arti bahwa dividen yang dibagikan tertinggi sebesar 100 persen. Nilai rata- rata (mean) sebesar 50,6867 memiliki arti 100 rupiah laba per lembar saham menghasilkan 50,6867 dividen per lembar saham, dengan standar deviasi sebesar 28,24744 menunjukkan bahwa tidak ada ketimpangan nilai DPR dari 13 perusahaan selama tiga tahun pengamatan.

Variabel keputusan pendanaan yang dinilai menggunakan ratio DER (Dept to Equity Ratio) adalah persentase total hutang dibagi dengan ekuitas perusahaan. Keputusan pendanaan memiliki nilai terendah (minimum) sebesar 0,08 yang terdapat pada perusahaan Industri Jamu dan Farmasi Sido Tbk pada tahun 2016, memiliki arti bahwa hutang perusahaan terendah sebesar 0,08 persen. Nilai tertinggi (maksimum) sebesar 2,12 yang terdapat pada Multi Bintang Indonesia Tbk pada tahun 2018, memiliki arti bahwa hutang perusahaan tertinggi sebesar 2,12 persen. Nilai rata-rata (mean) sebesar 0,6944 memiliki arti 100 rupiah ekuitas menghasilkan 0,6944 total hutang, sedangkan standar deviasi sebesar 0,50731 menunjukkan bahwa tidak ada ketimpangan nilai keputusan pendanaan dari 13 perusahaan selama tiga tahun pengamatan.

Variabel tingkat inflasi memiliki nilai terendah (minimum) sebesar 3,02 yang terdapat pada 13 perusahaan pada tahun 2016, memiliki arti bahwa tingkat inflasi terendah sebesar 3,02 persen. Nilai tertinggi (maksimum) sebesar 3,61 yang terdapat pada 13 perusahaan pada tahun 2017, memiliki arti tingkat inflasi tertinggi sebesar 3,61 persen. Nilai rata-rata (mean) sebesar 3,2533, sedangkan standar deviasi sebesar 0,25952 menunjukkan bahwa tidak ada ketimpangan nilai tingkat inflasi dari 13 perusahaan selama tiga tahun pengamatan.

Variabel tingkat suku bunga memiliki nilai terendah (minimum) sebesar 4,56 yang terdapat pada 13 perusahaan pada tahun 2017, memiliki arti bahwa tingkat suku bunga rendah sebesar 4,56 persen. Nilai tertinggi (maksimum) sebesar 6,00 yang terdapat pada 13 perusahaan pada tahun 2016, memiliki arti tingkat suku bunga tertinggi sebesar 6,00 persen. Nilai rata-rata (mean) sebesar 5,2067, sedangkan standar deviasi sebesar 0,60476 menunjukkan bahwa tidak ada ketimpangan nilai suku bunga dari 13 perusahaan selama tiga tahun pengamatan.

Variabel nilai tukar rupiah memiliki nilai terendah (minimum) sebesar 13,44 yang terdapat pada 13 perusahaan pada tahun 2016, memiliki arti bahwa nilai tukar mata uang terendah sebesar 13,44 persen. Nilai tertinggi (maksimum) sebesar 14,93 yang terdapat pada 13 perusahaan pada tahun 2016, memiliki arti nilai tukar mata uang tertinggi sebesar 14,93 persen. Nilai rata-rata (mean) sebesar 13,9733, sedangkan standar deviasi sebesar 0,68682 menunjukkan bahwa 
tidak ada ketimpangan nilai suku bunga dari 13 perusahaan selama tiga tahun pengamatan.

Perhitungan koefisien regresi linier berganda dilakukan dengan analisis regresi melalui software SPSS 18.0 for Windows, diperoleh hasil yang ditunjukan pada Tabel 2.

Tabel 2. Hasil Analisis Regresi Linier Berganda

\begin{tabular}{cllllll}
\hline Model & \multicolumn{5}{c}{ Standardized } \\
\cline { 3 - 6 } & \multicolumn{5}{c}{ Unstandardized Coefficients Coefficients } \\
\cline { 2 - 6 } & (Constant) & $-0,115$ & 0,112 & $-1,027$ & Sig. \\
\hline & ROE & 0,693 & 0,217 & 0,515 & 3,189 & 0,003 \\
& DPR & 0,064 & 0,106 & 0,079 & 0,597 & 0,555 \\
& DER & $-0,311$ & 0,140 & $-0,357$ & $-2,212$ & 0,034 \\
& Inflasi & $-3,849$ & 1,031 & $-4,296$ & $-3,734$ & 0,001 \\
& Suku Bunga & $-3,941$ & 1,038 & $-4,446$ & $-3,796$ & 0,001 \\
& Kurs & $-1,816$ & 0,516 & $-1,978$ & $-3,522$ & 0,001 \\
\hline
\end{tabular}

Sumber: Data Penelitian, 2019

Berdasarkan hasil analisis regresi linier berganda seperti yang disajikan pada Tabel 2. maka dapat dibuat persamaan regresi sebagai berikut:

$$
\bar{Y}=-0,115+0,693 X_{1}+0,064 X_{2}-0,311 X_{3}-3,849 X_{4}-3,941 X_{5}-1,816 X_{6}
$$

Hipotesis pertama menyatakan bahwa profitabilitas berpengaruh positif terhadap nilai perusahaan. Berdasarkan analisis regresi berganda, variabel profitabilitas memiliki nilai koefisien positif sebesar 0,693 dengan tingkat signifikansi sebesar 0,003 yang lebih kecil 0,05. Hal ini berarti variabel profitabilitas berpengaruh positif terhadap nilai perusahaan, sehingga hipotesis pertama $\left(\mathrm{H}_{1}\right)$ diterima. Hasil penelitian ini sejalan dengan hasil penelitian yang dikemukakan oleh Sintyana \& Artini (2018), Dewi \& Wirasedana (2018), Indasari \& Yadnyana (2018), serta Mursalim Alamzah \& Sanusi (2015) yang menyatakan bahwa profitabilitas berpengaruh positif terhadap nilai perusahaan.

Arah positif tersebut memiliki arti bahwa semakin meningkat profitabilitas yang di proksi dengan Tobin's $Q$ maka nilai perusahaan yang diperoleh akan meningkat. Teori sinyal Dalam mengemukakan tentang bagaimana seharusnya sebuah perusahaan memberikan sinyal kepada pengguna laporan keuangan. Salah satunya berupa informasi keuangan yang dapat dipercaya dan akan mengurangi ketidak pastian mengenai prospek perusahaan yang akan datang. Informasi keuangan yang mampu menjelaskan kinerja keuangan perusahaan tersebut dan dapat diukur dengan menghitung komponen-komponen laporan keuangan menjadi rasio keuangan.

Rasio keuangan yang digunakan adalah return on equity (ROE). ROE menunjukkan kemampuan perusahaan untuk menghasilkan laba atas modalnya sendiri. ROE digunakan untuk mengukur besarnya pengembalian terhadap investasi para pemegang saham. Angka tersebut menunjukkan seberapa baik manajemen memanfaatkan investasi para pemegang saham. Return on equity (ROE) memiliki hubungan yang positif dengan harga saham, sehingga semakin besar. Semakin tinggi profitabilitas maka semakin besar pula harga pasar, karena besarnya return on equity (ROE) memberikan indikasi bahwa pengembalian yang akan diterima investor akan tinggi sehingga investor akan tertarik untuk membeli saham tersebut, dan hal itu menyebabkan harga pasar saham 
cenderung naik dan selanjutnya akan meningkatkan nilai perushaaan (Hermuningsih, 2013). Return on equity (ROE) digunakan untuk mengukur besarnya pengembalian terhadap investasi para pemegang saham. Angka tersebut menunjukkan seberapa baik manajemen memanfaatkan investasi para pemegang saham.

Hipotesis kedua menunjukkan bahwa kebijakan dividen berpengaruh positif terhadap nilai perusahaan. Berdasarkan hasil analisis regresi berganda, variabel kebijakan dividen memiliki nilai koefisien positif sebesar 0,064 dengan tingkat signifikan sebesar 0,555 yang lebih besar dari 0,05. Hal ini berarti variabel kebijakan dividen tidak berpengaruh terhadap nilai perusahaan, sehingga hipotesis kedua $\left(\mathrm{H}_{2}\right)$ ditolak karena dari data hasil statistik deskriptif pada penelitian ini menunjukkan nilai perusahaan tidak bereaksi jika dividen dibagikan pada tanggal yang berbeda seperti pada saat pengumuman atau pembagian dividen, tergantung pada perusahaan tersebut sedangkan harga saham pada penutupan pada akhir tahun, sehingga dividen tidak mempengaruhi nilai perusahaan.

Meningkatnya nilai dividen tidak selalu diikuti dengan meningkatnya nilai perusahaan karena nilai perusahaan ditentukan hanya oleh kemampuan perusahaan menghasilkan laba dari aset-aset perusahaan atau kebijakan investasinya (Mardiyati, 2013). Beberapa penelitian tidak menemukan sampel tanggal Mardiyati (2013), dan Afzal \& Abdul (2015). Hal ini menunjukkan bahwa, meningkatnya dividen berturut-turut yang sesuai dengan metode pemilihan sampel penelitian tidak selamanya menjadi sinyal positif bagi investor. Hal tersebut timbul karena investor menganggap bahwa manajer perusahaan kurang peka terhadap peluang investasi yang dapat mengahasilkan keuntungan.

Hipotesis ketiga menyatakan bahwa keputusan pendanaan berpengaruh negatif terhadap nilai perusahaan. Berdasarkan analisis regresi berganda, variabel keputusan pendanaan memiliki nilai koefisien negatif sebesar $-0,311$ dengan tingkat signifikansi sebesar 0,034 yang lebih kecil 0,05. Hal ini berarti variabel keputusan pendanaan berpengaruh negatif terhadap nilai perusahaan, sehingga hipotesis ketiga $\left(\mathrm{H}_{3}\right)$ diterima. Hasil penelitian ini sejalan dengan hasil penelitian yang dikemukakan oleh Yunitasari (2016) dan Prihantini (2009) yang mendukung pernyataan bahwa debt to equity rasio berpengaruh negatif dan signifikan terhadap nilai perusahaan.

Arah negatif tersebut menunjukkan debt to equity ratio yang terlalu tinggi mempunyai sinyal buruk terhadap kinerja perusahaan sehingga berpengaruh terhadap nilai perusahaan, karena tingkat utang yang semakin tinggi berarti beban bunga perusahaan akan semakin besar dan akan mengurangi keuntungan.

Hipotesis keempat menyatakan bahwa tingkat inflasi berpengaruh negatif terhadap nilai perusahaan. Berdasarkan analisis regresi berganda, variabel inflasi memiliki nilai koefisien negatif sebesar -3,849 dengan tingkat signifikansi sebesar 0,001 yang lebih kecil 0,05. Hal ini berarti variabel inflasi berpengaruh negatif terhadap nilai perusahaan, sehingga hipotesis keempat $\left(\mathrm{H}_{4}\right)$ diterima. Hasil penelitian ini sejalan dengan hasil penelitian yang dikemukakan oleh Prihantini (2009), Permana \& Rahyuda (2018), serta Hamidah \& Hartini (2015) yang 
menyatakan bahwa tingkat inflasi berpengaruh negatif terhadap nilai perusahaan.

Arah negatif tersebut menunjukkan suatu kecenderungan akan naiknya harga barang-barang secara umum, yang berarti terjadinya penurunan nilai uang. Menurut Tandelilin (2010) Jika tingkat inflasi suatu negara mengalami penurunan, maka hal ini akan merupakan sinyal yang positif bagi investor seiring dengan turunnya risiko day a beli uang dan risiko penurunan pendapatan riil. Inflasi yang terlalu tinggi akan menyebabkan penurunan daya beli uang dan mengurangi tingkat pendapatan riil yang diperoleh perusahaan sehingga nilai perusahaan menurun yang mengakibatkan para investor enggan menanamkan dananya di perusahaan.

Hipotesis kelima menyatakan bahwa tingkat suku bunga berpengaruh negatif terhadap nilai perusahaan. Berdasarkan analisis regresi berganda, variabel tingkat suku bunga memiliki nilai koefisien negatif sebesar -3.941 dengan tingkat signifikansi sebesar 0,001 yang lebih kecil 0,05. Hal ini berarti variabel tingkat suku bunga berpengaruh negatif terhadap nilai perusahaan, sehingga hipotesis kelima $\left(\mathrm{H}_{5}\right)$ diterima. Hasil penelitian ini sejalan dengan hasil penelitian yang dikemukakan oleh Setiani et al. (2014), Noerirawan (2012), dan Rakhimsyah (2011) yang menyatakan bahwa tingkat suku bunga berpengaruh negatif terhadap nilai perusahaan.

Arah negatif tersebut menunjukkan suku bunga yang tinggi akan memberi sinyal negatif terhadap minat investor untuk menginvestasikan dananya ke pasar modal dan lebih memilih berinvestasi pada deposito sehingga aktivitas perdagangan saham akan menurun dan nilai perusahaan juga akan mengalami penurunan.

Hipotesis keenam menyatakan bahwa nilai tukar mata uang berpengaruh negatif terhadap nilai perusahaan. Berdasarkan analisis regresi berganda, variabel nilai tukar mata uang memiliki nilai koefisien negatif sebesar -1.816 dengan tingkat signifikansi sebesar 0,001 yang lebih kecil 0,05. Hal ini berarti variabel nilai tukar mata uang berpengaruh negatif terhadap nilai perusahaan, sehingga hipotesis keenam $\left(\mathrm{H}_{6}\right)$ diterima. Hasil penelitian ini sejalan dengan hasil penelitian yang dikemukakan oleh Mursalim Alamzah \& Sanusi (2015), Kusuma (2016), serta Al-abdallah et al. (2017) yang menyatakan bahwa nilai tukar mata uang berpengaruh negatif terhadap nilai perusahaan.

Arah negatif tersebut menunjukkan bahwa nilai tukar memberikan pengaruh negatif tidak signifikan terhadap nilai perusahaan. Hal ini berarti, apabila terjadi kenaikan nilai inflasi ataupun kenaikan nilai tukar mata IDR terhadap USD (kurs terapresiasi), maka akan menurunkan nilai perusahaan. Hal ini bisa dikaitkan dengan pemikiran bahwa apabila nilai tukar mata uang mengalami apresiasi, maka investor lebih cenderung memborong dollar karena murah dan memindahkan nilai investasinya di pasar modal ke dalam instrumen pasar valuta asing. Sehingga menurunkan harga saham tersebut, yang berarti menurunkan nilai perusahaannya.

Uji ketepatan model regresi bertujuan untuk mengetahui apakah semua variabel bebas yang diidentifikasi profitabilitas (ROE), kebijakan dividen (DPR), keputusan pendanaan (DER), tingkat inflasi, tingkat suku bunga, dan nilai tukar 
mata uang tepat digunakan memprediksi nilai perusahaan. Uji ini sering juga disebut dengan uji F, dengan hasil yang dapat dilihat pada Tabel 3. berikut:

Tabel 3. Hasil Uji F

\begin{tabular}{lllllll}
\hline Model & & Sum of Squares & Df & Mean Square & F & Sig. \\
\hline 1 & Regression & 24,583 & 6 & 4,097 & 9,772 & $0,000^{a}$ \\
& Residual & 24,583 & 32 & 4,097 & & \\
& Total & 38,000 & 38 & & & \\
\hline
\end{tabular}

Sumber: Data Penelitian, 2019

Hasil uji $\mathrm{F}$ ( $F$ test) menunjukkan bahwa nilai $\mathrm{F}$ hitung sebesar 9,772 dengan nilai signifikansi $P$ value 0,000 yang lebih kecil dari $a=0,05$, ini berarti model yang digunakan pada penelitian ini adalah layak digunakan. Hasil ini mempunyai arti bahwa ada pengaruh signifikan antara faktor profitabilitas $(\mathrm{ROE})\left(\mathrm{X}_{1}\right)$, kebijakan dividen $(\mathrm{DPR})\left(\mathrm{X}_{2}\right)$, keputusan pendanaan $(\mathrm{DER})\left(\mathrm{X}_{3}\right)$, tingkat inflasi $\left(X_{4}\right)$, tingkat suku bunga $\left(X_{5}\right)$, dan nilai tukar mata uang $\left(X_{6}\right)$ secara simultan terhadap nilai perusahaan.

Untuk mengetahui dan mengukur kemampuan model dalam menerangkan variasi variabel independen digunakan koefisien determinasi $\left(R^{2}\right)$. Peneliti menggunakan $R^{2}$ pada saat mengevaluasi yang mana model regresi terbaik, karena nilai $R^{2}$ dapat naik atau turun apabila satu variabel independen ditambahkan ke dalam model. Adapun hasil uji koefisien determinasi dapat dilihat pada Tabel 4 . berikut:

Tabel 4. Hasil Uji koefisien determinasi

\begin{tabular}{|c|c|c|c|c|}
\hline Model & $\mathrm{R}$ & R Square & Adjusted R Square & $\begin{array}{l}\text { Std. Error of the } \\
\text { Estimate }\end{array}$ \\
\hline 1 & $0,804^{\mathrm{a}}$ & 0,647 & 0,581 & 0,64751683 \\
\hline
\end{tabular}

Sumber: Data Penelitian, 2019

Hasil uji memberikan hasil dimana diperoleh besarnya $R^{2}$ (koefisien determinasi yang telah disesuaikan) pada Tabel 4 . adalah 0,647 . Ini berarti variasi Nilai perusahaan dapat dipengaruhi secara signifikan oleh variabel profitabilitas $(\mathrm{ROE})\left(\mathrm{X}_{1}\right)$, kebijakan dividen $(\mathrm{DPR})\left(\mathrm{X}_{2}\right)$, keputusan pendanaan $(\mathrm{DER})\left(\mathrm{X}_{3}\right)$, tingkat inflasi $\left(X_{4}\right)$, tingkat suku bunga $\left(X_{5}\right)$, dan nilai tukar mata uang $\left(X_{6}\right)$ sebesar 64,7 persen sedangkan sisanya sebesar 35,3 dijelaskan oleh faktor-faktor lain.

\section{SIMPULAN}

Penelitian ini menghasilkan kesimpulan mengenai bagaimana signalling theory menjelaskan pengaruh profitabilitas, kebijakan dividen, keputusan pendanaan, inflasi, suku bunga, dan nilai tukar mata uang terhadap nilai perusahaan. Penelitian ini juga dapat memberikan wawasan mengenai nilai perusahaan, profitabilitas, kebijakan dividen, keputusan pendanaan, tingkat inflasi, tingkat suku bunga dan nilai tukar mata uang. Penelitian ini juga mendukung teori sinyal, yaitu suatu tindakan yang diambil oleh manajemen perusahaan yang memberikan informasi kepada para investor mengenai prospek perusahaan dimasa mendatang atau perkembangan perusahaan. Apabila profitabilitas yang tinggi menunjukkan prospek perusahaan yang bagus dimasa mendatang sehingga menarik minat investor dalam menanamkan saham dan juga peningkatan dalam tingkat pembayaran dividen dianggap sebagai sinyal yang akan memberikan keuntungan, maka dari itu sesuai dengan teori sinyal, hal 
tersebut dapat memberikan sinyal-sinyal yang baik (good news) kepada publik sehingga dapat menaikkan nilai perusahaan yang dapat tercermin dari harga saham perusahaan tersebut.

Berdasarkan hasil penelitian yang didapatkan, penelitian ini dapat memberikan kontribusi positif bagi semua pihak khususnya perusahaan dan pengguna utama laporan keuangan. Bagi perusahaan, penelitian ini dapat memberikan referensi tambahan mengenai pencapaian nilai perusahaan yang maksimal dengan meningkatkan profit dan meningkatkan pembayaran dividen. Bagi pengguna laporan keuangan seperti investor, penelitian ini dapat memberikan informasi untuk bahan pertimbangan dalam melakukan investasi.

\section{REFERENSI}

Al-abdallah, S. Y., Ibrahim, N., \& Aljarayesh, A. (2017). Influence of Interest Rate , Exchange Rate and Inflation on Common Stock Returns of Amman Stock Exchange , Jordan. International Journal of Economics, Commerce and Management, V(10), 589-601.

Atmaja, L. S. 2003. (2003). Manajemen Keuangan. Yogyakarta: Andi Offset.

Bhattacharya, S. (1979). Imperfect Information, Dividend Policy, and "The Bird in the Hand" Fallacy. The Bell Journal of Economics, 10(1), 259. https://doi.org/10.2307/3003330

Chandra, K., Fachrudin, Sadalia, I., \& Siburian, R. (2017). The Effect of Capital Structure, Profitability and Dividend Policy on Intrinsic Value of Firm. Journal of Finance and Accounting, 8(14), 101-107.

Dj, A. M., Artini, L. G. S., \& Suarjaya, A. . G. (2012). Pengaruh Kinerja Keuangan terhadap Nilai Perusahaan dengan Kebijakan Dividen sebagai Variabel Pemoderasi. Jurnal Manajemen, Strategi Bisnis, Dan Kewirausahaan, 6(2), 130138. https://doi.org/10.1017/CBO9781107415324.004

French, F. \&. (1998). The study effect agency theory and signaling theory on the level of voluntary disclosure of listed companies in Tehran Stock Exchange. 6(1), 174-184.

Hady. (2016). Pengaruh Keputusan Investasi, Keputusan Pendanaan dan Kebijakan Dividen Terhadap Nilai Perusahaan. Jurnal Manajemen Dan Bisnis Sriwijaya, 16(3), 164-176. https://doi.org/10.29259/jmbs.v16i3.7380

Hamidah, Hartini, U. M. (2015). Dan Risiko Finansial Terhadap Nilai Perusahaan Sektor Properti Tahun 2011-2013. Jurnal Riset Manajemen Sains Indonesia, 6(1), 395-416.

Harahap. (2010). With Capital Structure As Intervening Variable ( in Plantation Sub. E-Jurnal Manajemen Unud, 303.

Herman. (2003). Perbedaan Pengaruh Inflasi, Tingkat Suku Bunga dan Nilai Tukar Rupiah/US Dollar terhadap.

Hermuningsih. (2013). Pengaruh Ukuran Perusahaan, Kebijakan Dividen Terhadap Nilai Perusahaan. Semarang : Universitas Diponegoro.

Hidayati, E. E. (2010). Analisis Pengaruh Der, Dpr, Roe Dan Size Terhadap Pbv Perusahaan Manufaktur Yang Listing Di Bei Periode 2005-2007. Jurnal Bisnis Strategi, 19(2), 166-174.

Indasari, A. P., \& Yadnyana, I. K. (2018). Pengaruh Profitabilitas, Growth Opportunity, Likuiditas, dan Struktur Modal Pada Nilai Perusahaan. EJurnal Akuntansi, 22, 714. https://doi.org/10.24843/EJA.2018.v22.i01.p27 
Jr, G. (2016). Dividend Policy and Its Impact on Firm Value: A Review of Theories and Empirical Evidence. ApeejayJournal of Management Sciences and Technology, 3(3), 59-69.

Judisseno. (2002). Influence of capital structure, size and growth on profitability and corporate value. In International Journal of Business and Finance Management Research (Vol. 4).

Kandir, S. (2008). Macroeconomic variables, firm characteristics and stock returns: evidence from Turkey. International Research Journal of Finance and Economics, 16(1), 35-45.

Kewal. (2014). Influence of capital structure on profitability: Empirical Evidence from listed Nigerian banks. IOSR Journal of Business and Management, 16(11), 22-28. https://doi.org/10.9790/487x-161142228

Kurniawan, I. G. E., \& Putra, I. N. W. A. (2019). The Effect of Profitability, Debt Policy, and Dividend Policy on Company Value. E-Jurnal Akuntansi, 28(3), 1783-1800.

Kusuma. (2016). The Effects of Dividend Policy on Firm Value for Commercial Banks in Kenya. (October).

M'rabet, R., \& Boujjat, W. (2016). The Relationship Between Dividend Payments And Firm Performance: A Study Of Listed Companies In Morocco. European $\begin{array}{llll}\text { Scientific Journal, } & \text { ESJ, }\end{array}$ https://doi.org/10.19044/esj.2016.v12n4p469

Manurung, S. D., Suhadak, \& Nuzula, N. F. (2014). the Influence of Capital Structure on Profitability and Firm Value. Jurnal Administrasi Bisnis, 7(2), 18.

Mardiyati, U. (2013). Pengaruh Kebijakan Dividen, Kebijakan Hutang dan Profitabilitas Terhadap Nilai Perusahaan Manufaktur yang Terdaftar di Bursa Efek Indonesia (BEI) Periode 2005-2010. Journal of Chemical Information and Modeling, 53(9), 1689-1699. https://doi.org/10.1017/CBO9781107415324.004

Martini, Ni Nyoman Moeljadi Djumahir, and D. A. (2014). Factors Affecting Firm Value: Theoretical Study on Public Manufacturing Firms in Indonesia. South East Asia Journal of Contemporary Business, Economics and Law, 5(2), 615.

Mulianti. (2010). analisis faktor faktor yang mempengaruhi kebijakan hutang dan mempengaruhnya terhadap nilai perusahaan.

Mursalim Alamzah, N., \& Sanusi, A. (2015). Financial Decision, Innovation, Profitability and Company Value: Study on Manufacturing Company Listed in Indonesian Stock Exchange. Information Management and Business Review, $7(2), 7278$.

Ningsih, P. P., \& Indarti, I. (2012). The Influence of Investment Decision, Financing Decision, And Dividend Policy on Firm Value (Case Study at The Manufacturing Companies Listed in Indonesia Stock Exchange in The PUTRI PRIHATIN NINGSIH IIN INDARTI. Jurnal Kajian Akutansi Dan Bisnis, 1(1), 1-23.

Noerirawan, M. R. (2012). Pengaruh Faktor Internal Dan Eksternal Perusahaan Terhadap Nilai Perusahaan (Studi Empiris pada Perusahaan Manufaktur yang terdaftar di Bursa Efek Indonesia Periode 2007-2010). Pengaruh Faktor 
Internal Dan Eksternal Perusahaan Terhadap Nilai Perusahaan (Studi Empiris Pada Perusahaan Manufaktur Yang Terdaftar Di Bursa Efek Indonesia Periode 2007-2010), 1(1), 582-593.

Octaviani, N., \& Astika, I. (2016). Profitabilitas Dan Leverage Sebagai Pemoderasi Pengaruh Kebijakan Dividen Pada Nilai Perusahaan. E-Jurnal Akuntansi, 14(3), 2192-2219.

Permana, A. A. N. B. A., \& Rahyuda, H. (2018). Pengaruh Profitabilitas, Solvabilitas,Likuiditas, Dan Inflasi Terhadap Nilai Perusahaan. E-Jurnal $\begin{array}{llll}\text { Manajemen Universitas } & \text { Udayana, }\end{array}$ https://doi.org/10.24843/ejmunud.2019.v08.i03.p15

Pratama, I., \& Wirawati, N. (2016). Pengaruh Struktur Modal Dan Profitabilitas Terhadap Nilai Perusahaan Dengan Kepemilikan Manajerial Sebagai Pemoderasi. E-Jurnal Akuntansi, 15(3), 1796-1825.

Pratiwi, N. P. D., \& Mertha, M. (2017). Pengaruh Kebijakan Hutang dan Profitabilitas Pada Nilai Perusahaan Dengan Kebijakan Dividen Sebagai Variabel Pemoderasi. E-Jurnal Akuntansi Universitas Udayana, 20(2), 14461475.

Prihantini. (2009). Pengaruh Inflasi, Nilai Tukar, ROA, DER dan CR terhadap Return Saham Industri Real Estate and Property yang Listed di Bursa Efek Indonesia periode 2003 - 2006.

Prihantini, R. (n.d.). Pengaruh Inflasi, Nilai Tukar, ROA, DER dan CR terhadap Return Saham industri real estate and property yang listed di Bursa Efek Indonesia periode 2003 - 2006.

Raharjo, Sugeng Suartawan, I. G. N. P. A., \& Yasa, G. W. (2017). Pengaruh Investment Opportunity Set dan Free Cash Flow Pada Kebijakan Dividen dan Nilai Perusahaan. Jurnal Ilmiah Akuntansi Dan Bisnis, 63. https://doi.org/10.24843/jiab.2016.v11.i02.p01

Rakhimsyah. (2011). Hubungan Kebijakan Hutang, Insider Ownership Dan Kebijakan Dividen Dalam Mekanisme Pengawasan Masalah Agensi Di Indonesia. Jaai, 10(2), 121-136.

Riska, P., Dewi, A., \& Putri, I. G. A. M. A. D. (2017). Pengaruh Kebijakan Dividen Pada Nilai Perusahaan Dengan Pengungkapan Csr Dan Good Corporate Governance Sebagai Pemoderasi. E-Jurnal Akuntansi, 21, 173-199.

Rizqia, D. A., Aisjah, S., Program, P., \& Java, E. (2013). Effect of Managerial Ownership, Financial Leverage, Profitability, Firm Size, and Investment Opportunity on Dividend Policy and Firm Value. 4(11), 120-130.

Rukhimsyah. (2011). Dividend Policy, Growth, and the Valuation of Shares. Revue Des Maladies Respiratoires Actualites, 2(4), 326-329. https://doi.org/10.1016/S1877-1203(10)70085-9

Setiani, Rury. Maimunah, S., \& Hilal, S. (2014). Pengaruh Keputusan Investasi, Keputusan Pendanaan, Kebijakan Dividen Dan Tingkat Suku Bunga Terhadap Nilai Perusahaan. JIAFE (Jurnal Ilmiah Akuntansi Fakultas Ekonomi), 6(2), 42-49. https://doi.org/10.34204/jiafe.v6i2.531

Setiani, R., Maimunah, S., \& Hilal, S. (2014). Pengaruh Keputusan Investasi, Keputusan Pendanaan, Kebijakan Dividen Dan Tingkat Suku Bunga Terhadap Nilai Perusahaan. JIAFE (Jurnal Ilmiah Akuntansi Fakultas Ekonomi), $6(2), 42-49$. 
Sintyana, I. P. H., \& Artini, L. G. S. (2018). Pengaruh Profitabilitas, Struktur Modal, Ukuran Perusahaan Dan Kebijakan Dividen Terhadap Nilai Perusahaan. E-Jurnal Manajemen Universitas Udayana, 8(2), 757. https://doi.org/10.24843/ejmunud.2019.v08.i02.p07

Sucuahi, W., \& Cambarihan, J. M. (2016). Influence of Profitability to the Firm Value of Diversified Companies in the Philippines. Accounting and Finance Research, 5(2). https://doi.org/10.5430/afr.v5n2p149

Tandelilin, E. (2010). Analisa Investasi dan Manajemen Portfolio. Edisi Pertama, Yogyakarta: BPFE.

Ugy, S. \&. (2007). Pengaruh Struktur Kepemilikan Saham, Leverage, Faktor Intern Dan Faktor Ekstern Terhadap Nilai Perusahaan (Studi empirik pada perusahaan manufaktur dan non manufaktur di Bursa Efek Jakarta ). (1976), 41-48.

Ustiani, N. (2015). Pengaruh Struktur modal, Kepemilikan Manajerial, Keputusan Investasi, Kebijakan Deviden, Keputusan Pendanaan dan Profitabilitas Terhadap Nilai Perusahaan (Studi Pada Perusahaan Keuangan dan Perbankan Di BEI Tahun 2009-2013). Jurnal Akuntansi Fakultas Ekonomi Universitas Pandanaran Semarang, 1-20.

Wangbangpo, P., \& Sharma, S. C. (2002). Stock Market and Macroeconomic Fundamental Dynamic Interaction : ASEAN-5 Countries.

Windasari, A. N. (2015). Analisis Pengaruh Tingkat Inflasi, Nilai Kurs Rupiah, Tingkat Suku Bunga terhadap Harga Saham di Bursa Efek Indonesia Tahun 2009-2013. E-Jurnal Manajemen UMS.

Wirasedana, I. W. P. (2018). Pengaruh Keputusan Investasi, Keputusan Pendanaan, Kebijakan Dividen dan Tingkat Inflasi Terhadap Nilai Perusahaan Luh Putu Utami Kartika Dewi 1 Fakultas Ekonomi dan Bisnis Universitas Udayana (Unud ), Bali , Indonesia Fakultas Ekonomi dan Bisnis Unive. 23, 813-841.

Yuniasari. (2016). The impact of dividend policy on firm value: A panel data analysis of Romanian listed firms. Journal of Public Administration, Finance and Law, 10(10), 107-112.

Yunitasari. (2016). The Impact of Dividend Policy on Firm Value: A Panel Data Analysis of Romanian Listed Firms. Journal of Public Administration, Finance and Law, 10(10), 107-112. 